\title{
$\bigcirc$ vere ius summum, summa malitia: Poskus žanrske opredelitve in namembnosti Hieronimove Ep. 1
}

\section{Domen Iljaš $^{\star}$ in Miran Špelič OFM ${ }^{* \star}$}

UVOD

Antična epistolografija je izzivalno področje. Ker smo v našem času priče velikim premikom v komunikaciji, ki sta jo prinesla telefon in internet, nas še toliko bolj izzivajo komunikacijski zasuki v antiki, še posebej v pozni antiki. Iz tega obdobja imamo namreč že kar precej gradiva, ki se ponuja za analizo, ta pa nam postreže z novimi uvidi $\mathrm{v}$ življenje in miselnost tistega časa.

Hieronimov zbornik pisem obsega 155 enot neenakomerne dolžine. ${ }^{1}$ Nekaj poskusov sortiranja in grupiranja zasledimo že pri avtorju samem, za zadnjo redakcijo zbirke pa seveda najbrž ne bomo nikoli zvedeli, kdo jo je izdelal.

$\mathrm{V}$ naši razpravi bomo pod drobnogled vzeli njegovo prvo pismo, ki je morda prvo tudi v kronološkem smislu. Predvsem se bomo lotili njegove zvrstnosti: koliko in kako se sme, če se sploh sme, prištevati v epistolografski žanr? Dejstvo je, da se vanj lahko vrine marsikaj in ne le »razpolovljeni pogovor«, kakor se je glasila najbolj klasična antična

* Filozofska fakulteta Univerze v Ljubljani, Aškerčeva 2, 1000 Ljubljana; domen.iljas@gmail.com.

** Teološka fakulteta Univerze v Ljubljani, Poljanska cesta 4, Ljubljana; miran.spelic@teof.uni-lj.si.

1 Od tega naj bi jih Hieronim napisal 123. O njihovem številu in tematski kategorizaciji v dodatku svoji študiji o Hieronimovem epistularnem opusu obširno razpravlja Cain, The Letters of Jerome, 207-19. 
definicija pisma. Fleksibilnost žanra dokazuje zlasti razvoj fiktivnih pisem, ki nas želijo prepričati, da gre za resnično dopisovanje, v resnici pa pod to krinko nosijo neko drugo sporočilo.

Po poskusu datacije pisma si bomo ogledali umestitev tega besedila na začetek Hieronimovega pisemskega korpusa. Retorični analizi in primerjavi s ciceronijanskimi zgledi bo sledila zgodovinska analiza in iskanje zgodovinskega metadiskurza, ko avtor s preteklimi dogodki v bistvu opisuje stanje v svojem času. Slednjič bomo pozorni na nenavaden prenos predkonstantinskih motivov (ko je imperij še preganjal Cerkev) v čas močne Cerkve in oslabljenega imperija. Podoben motiv preobrata nam bo ponudila tudi analiza zamenjanih spolnih vlog protagonistov v pismu opisane zgodbe. Slednjič pa bomo na osnovi primerjav z drugimi Hieronimovimi spisi skušali ugotoviti avtorjev namen pri pisanju tega pisma, ki gotovo daleč presega željo po informiranju prijatelja o nenavadnem dogodku, ki se morda sploh ni zgodil.

\section{NASTANEK IN UMESTITEV PISMA 1}

Prvo Hieronimovo pismo je nastalo okoli leta 375 in tako ni le prvo izmed njegovih pisem, ampak njegovo najzgodnejše ohranjeno delo sploh. Naslovnik Inocencij je pripadal Hieronimovemu oglejskemu krogu, sledil mu je tudi v Sirijo, kjer je umrl približno v času, ko je nastalo drugo pismo. Jedro tega pisma je zanimivo, saj gre za Hieronimov prvi poskus v tedaj vse bolj priljubljenem literarnem žanru - legendi o mučeništvu. Opaziti je, da poskuša tipični motiv iz časov preganjanj "reciklirati « v povsem novi dobi: spremeni se le to, da dekle ni mučeno zaradi vere, temveč zaradi svoje kreposti, ki pa seveda ni nič drugega kot pravi izraz pobožnosti. ${ }^{2}$ Vsi drugi elementi ostajajo tako rekoč

1 Slovenski prevod pisma, ki ga je pripravil Janez Potisek, je objavljen v reviji Tretji dan: Hieronim, »Pisma 1, 2, 8, 9«, 47-52. V pripravi je tudi prevod celotnega Hieronimovega epistolarija, ki bo pri Celjski Mohorjevi družbi izšel še letos.

2 V ozadju se namreč že kaže nastajajoča nova teologija, da krepostno življenje nadomešča mučeništvo. Hieronim tu pravzaprav ponudi sintezo mučeništva in krepostnega življenja; prav to nakazuje, da je krščanska etika v tej dobi, ko se je po koncu preganjanj morala vzpostaviti na novih temeljih, doživljala formativne spremembe. Nenazadnje je ravno v času nastanka pisma, konec leta 374, Ambrož postal škof v Milanu. Kmalu (1. 378) v svojem nagrobnem govoru bratu Satiru prvič uporabi pojem kardinalnih kreposti: "Superest, ut ad conclusionem cardinalium virtutum etiam partes in eo debeamus advertere $(D e$ excessu fratris Satyri 1.57). Platonova etika kreposti, ki so jo nadaljevali stoiki, preko Ambroževe in Hieronimove misli dobiva teološke temelje v posnemanju 
enaki: na smrt jo obsodi krut oblastnik, dogajanje je postavljeno v gledališče, opisi mučenja in usmrtitve so zelo nazorni, čudeži si sledijo drug za drugim, ob tem pa publika niha od hlepenja po okrutnosti do množičnih spreobrnjenj. Dokončna rešitev - v novi realnosti rimskega imperija, ki mu sedaj vlada kristjan - ni nič drugega kot clementia Caesaris, kar vsekakor predstavlja novost.

Gre torej za zanimiv in vsebinsko bogat dokument, četudi so ga še sredi prejšnjega stoletja mnogi raziskovalci ${ }^{3}$ opredeljevali kot preobloženo, manieristično retorično vajo mladega, izobraženega in ambicioznega, a predvsem neizkušenega pisca. Toda kdor pusti prenagljene interpretacije ob strani, hitro ugotovi, da ne gre zgolj za retorično (pre)bogat tekst, temveč za prvovrsten verski, zgodovinski, družbeni in kulturni spomenik Hieronimovega časa in tokov, v katere je bil vpet. Mogoče uvodoma ni odveč poudariti, ${ }^{4}$ da gre vseskozi za izrazito ideološko, programsko delo. Resda gre za Hieronimov prvi poskus v legendi o mučeništvu kot hagiografski literarni zvrsti, vendar se ta ne giblje povsem znotraj tradicionalne hagiografske naracije; prav zato je avtorju, glede na njegovo kasnejšo obširno obdelavo tega žanra, ${ }^{5}$ nedvomno uspel. Ta poskus torej ni le nekoliko prepotentna in preveč hibridna neuspela vaja, ampak prava umetnina. ${ }^{6}$

Ta teza pa šele načne osrednja vprašanja; sporna je že sama datacija. Tradicionalno, na podlagi dogodkov in razmer, opisanih v pismu, se nastanek uvršča v čas po 370, natančneje okrog leta 375 . $^{7}$ Seznam svojih del, napisanih do leta 393 , ki ga je Hieronim vključil v svojo

Kristusa in postane temeljni znak krščanske osebe - Hieronimova mučenka je pravzaprav exemplum novega, resnično krepostnega kristjana, ki moč za vztrajanje kljub nasprotovanju črpa iz Boga.

3 Precej takih mest navaja Rebenich, Jerome, 30; prim. Coppieters et al., "Martyrdom, Literary Experiment and Church Politics in Jerome's Epistula Prima to Innocentius, on the septies percussa«, 386 .

4 Prim. Coppieters et al., »Martyrdom, Literary Experiment«, 386; 407-8.

5 Kmalu po nastanku tega pisma je izdal Vita Pauli (ok. 376). Njegov De viris illustribus, obsežen spis 135 kratkih življenjepisov v Svetonijevem slogu, ki pa ni izključno hagiografski, saj se zaključi celo z avtobiografijo, je nastal okoli leta 392 (za pregled Hieronimove hagiografske dejavnosti prim. Barnes, Early Christian Hagiography and Roman History, 170-92). Sploh lahko Hieronimova hagiografska dela štejemo za začetke latinske hagiografije in tako tudi ni nič čudnega, da so mu pripisovali psevdoepigrafski Martyrologium Hieronymianum, katerega začetki v 5. stoletju naj bi segali prav na področje njegovega domačega Ogleja in je postal vir vseh kasnejših rimskih martirologijev.

6 Prim. Rebenich, Jerome, 30.

7 Za nekaj bibliografije o tem vprašanju prim. prav tam. 
avtobiografijo v De viris illustribus, ponuja precej natančen vpogled v njegovo zgodnje ustvarjanje. Navaja dve knjigi pisem, Epistolarum ad diversos librum unum in Ad Marcellam epistolarum librum unum, ${ }^{8}$ ter, po posameznih naslovih, sedem samostojnih pisem. ${ }^{9}$ Glede na to, da prvo pismo ni poimensko navedeno, bi moralo torej spadati v knjigo Ad diversos, toda Cain o tem močno dvomi. ${ }^{10}$ Razlog za to vidi predvsem v rokopisni tradiciji, kjer se Ep. 1 ob preostalih zgodnjih pismih ${ }^{11}$ pojavlja redko, ter tudi v samem Hieronimovem seznamu, ki naj bi bil zasnovan kronološko in kot prvo delo navaja De vita Pauli, Ad diversos pa šele takoj za njim. Na podlagi tega Cain predlaga rekonstrukcijo; Hieronimov prvi liber naj bi tako vseboval pisma 2-13 in 15-17.

Zdi se, da se rešitev problema tako čedalje bolj izmika, saj to, da Ep. 1 Hieronim ni vključil na svoj seznam, morda sugerira tudi kasnejšo datacijo. Vendar pa tako Cain kot tudi Coppieters et al. v tem ne vidijo posebnega problema, saj Hieronimov seznam že tako ni popoln ${ }^{12}$ oziroma je mogoče pri tem pismu tudi iz vsebine sklepati na uveljavljeno datacijo. ${ }^{13}$ Ta je še toliko enostavnejša, če obravnavamo naslovnika Inocencija kot resnično osebo in ne le kot »literarno ime« - pismo bi, glede na retorične prijeme in vsebino, namreč lahko bilo le slikovit debitantski nastop, ki se ga je uveljavljeni asketski pisec v zrelejših letih tako sramoval, da ga je v svojem curriculum vitae raje zamolčal. ${ }^{14}$ Toda po drugi strani je tudi v tretjem pismu omenjen prijatelj Inocencij, ${ }^{15} \mathrm{ki}$ je spremljal Hieronima v Antiohijo in tam tudi umrl (torej nekje okoli leta 375 , kar tako lahko predstavlja terminus post quem). ${ }^{16}$ Sploh se zdi,

8 Hier., Vir. ill. 135.

9 Hier., Ep. 14, 18a, 18b, 20, 21, 22, 36, 39; prim. Cain, The Letters of Jerome, 13.

10 Cain, The Letters of Jerome, 14-15.

11 Do Ep. 17, torej do leta 382, ko se Hieronim vrne v Rim. Iz istega razloga, pa tudi zato, ker ga tudi Hieronim omenja posebej, Cain izloči tudi pismo 14.

12 Cain, The Letters of Jerome, 15; Coppieters et al., "Martyrdom, Literary Experiment $«, 385-6$.

13 Hieronim je pri Evagriju zagotovo bival kmalu po 370 (prim. Rebenich, Jerome, 6-9), Valentinijan II. je zavladal leta 375, papež Damaz I. je Avksencija obsodil na dveh sinodah ok. leta 369 , ta pa je umrl 374 - in zdi se, da je Hieronim še nekako pod vtisom tega dogodka (Hier., Ep. 1.15).

14 Hieronim tudi sam eksplicitno priznava, da se svojih retorično prebogatih in pretirano šolskih mladostnih literarnih poskusov sramuje (Hier., Ep. 52.1).

15 Hier., Ep.3.3.1.

16 Probleme $\mathrm{z}$ datacijo obširno obravnava tudi Scourfield, »Literary Commentary on Jerome, Letters 1, 60, 107«, 33-36, ki na podlagi poteka Hieronimovega potovanja na vzhod imperija in njegovih stikov z Rufinom, Evagrijem in Inocencijem postavi nastanek pisma v prvo polovico 1. 375 . 
da pravi namen pisma ni bil pisati Inocenciju, najsi bo živ, mrtev ali neobstoječ, temveč napisati panegirik oziroma enkomij ${ }^{17}$ Evagriju in njegovim delom ${ }^{18}$ - in panegirik brez objave nima nikakršnega smisla. Ne glede na to, ali je bil Inocencij resnično naslovnik ali ne, se torej v pismu skriva dovolj indicev tako za čas nastanka kakor tudi za namen in željo po objavi.

\section{PISMO KOT RETORIČNA VAJA?}

V tej luči zanimiva in od njegovih preostalih zgodnjih pisem različna je že sama struktura pisma, saj se drži jasne, retoriške členitve in ima obliko okvirne pripovedi: uvodna sta prva dva odstavka, paragrafi 3-14 predstavljajo jedro pisma, torej pripoved o mučeništvu nedolžne ženske, Hieronim pa v naracijo ves čas vstavlja svoje komentarje in druge retorične elemente. Že uvodne besede prvega odstavka tako v celoti spominjajo na tipično antično epistulo, spadajo v Ciceronov besednjak ${ }^{19}$ in tudi topos "afektirane skromnosti«, ki ga ubere takoj za njimi, ni tuj ne antiki ne avtorju samemu. ${ }^{20}$ Celoten prvi odstavek je zgleden primer sledečega:

S tisoč drugimi topoi in konvencijami antične retorike je v literaturo krščanskega srednjega veka prišla tudi afektirana skromnost. Glavni posrednik pri tem je bil bržkone sv. Hieronim. [...] Te Hieronimove izjave so tipične - a ne za krščansko naravnanost, temveč za afektirani manierizem poznorimske književnosti, skupen poganom in kristjanom. ${ }^{21}$

Hieronima torej k pisanju saepe sili prijatelj, on se tega brani in navaja dva pričakovana, malodane tipska razloga: ker se sermo humanus ne more kosati z laus coelestis in ker je zaradi pomanjkanja kreposti, nateksta pa prestavlja precej gostobeseden opis mučeništva, se morda še toliko bolj zdi, da je Hieronim hvalnico Evagriju dopisal le zato, da bi imel dober razlog za objavo. In to nikakor ni zadnje njegovo pismo, ob katerem bi lahko prišli do takega zaključka (prim. Movrin, Fidus interpres, 64-65). O vlogi tega Hieronimovega sopotnika prim. str. 108-12.

19 Prim. Cic., Fam. 12.13; še toliko bolj se zdi, da bi lahko Hieronim tu, tudi vsebinsko, aludiral na Marciala: "Saepe mihi dicis, Luci carissime Iuli, / 'Scribe aliquid magnum: desidiosus homo es'« (Mart., Epigr. 1.107.1-2).

20 Curtius, Evropska literatura in latinski srednji vek, 82-84.

21 Curtius, Evropska literatura in latinski srednji vek, 378-79. 
tančneje zaradi lenobe, ostal brez »daru govora«. Nič nepričakovanega torej in nič, česar ne bi mogli videti že v poganski antiki - v sodnih govorih, pri Ciceronu, Izokratu itd. Tudi Hieronim želi dajati glede na zvrst pričakovani vtis, da se zadeve loteva le, ker ga je prijatelj večkrat prosil; lahko se nam celo zdi, da je prvi odstavek subtilno oblikoval v obliki takšnega dialoga: Ep. 1.1.1 omenja prijateljevo večkratno prigovarjanje, naj mu poroča o čudežu, miraculus rei. Odlomek 1.1.2 navaja njegovo zavrnitev, v katero je očitno zdaj, ko je stvar že napisal, ${ }^{22}$ še bolj prepričan, v 1.1.3 pa ponovno navede prijateljev odgovor, ki ga nasprotno odvrne od dvoma $v$ lastne sposobnosti in ga prepričuje, da je pomemben namen in da naj se zanese le na lastno vero v Verbum. ${ }^{23}$

Nasploh pa za Hieronima velja: poznavanje in navezave na Ciceronova dela kot tudi na temeljne zglede množice kasnejših avtorjev, na katere opozarja Curtius, pri njem niso le možni, temveč so gotovi. Tako je recimo izmed njegovih zgodnjih pisem osmo, četudi je kratko, še posebej zasnovano kot referenca na Cicerona, hkrati pa služi kot nepogrešljiv dokaz, da je $\mathrm{v}$ teh letih bivanja na Bližnjem vzhodu mladi Hieronim poleg obilice Plinija ${ }^{24}$ prebiral tudi Ciceronove spise o retoriki. ${ }^{25}$ Nenazadnje mu je bilo zaradi tega celo, četudi v sanjah, sojeno pred nebeškim tronom. ${ }^{26}$

Drugi odstavek sledi konceptu dialoga, orisanega zgoraj, in v celoti predstavlja Hieronimov odgovor prijatelju, pravzaprav poslednjo stvar, ki jo bo Hieronim »rekel na to temo«, preden se bo uklonil njegovi volji. In očitno se Hieronimu nikakor ne mudi končati s skromnostnimi obrazci, saj je drugi odstavek že sam po sebi vaja v slogu. Začne s tipičnim retoričnim vprašanjem, ki povzema dotedanjo formulacijo: naloge ni zmožen izpolniti, odbiti prijatelja pa je predrzno. To mu služi za uvod v precej daljšo in tudi morda najbolj klasično primero. Neizkušen in mlad je postavljen za poveljnika ladje sredi nevarnega morja in le Sveti Duh je tisti, po čigar milosti bi lahko varno dospel $\mathrm{v}$ pristan. Toda še v tem primeru bo ohranil skromnost, gubernator

Je torej Hieronim uvod v pismo pisal naknadno, ko je preostanek že dokončal? Glede na strukturo bi bilo kaj takega povsem možno. Ni nemogoče, da je podobno z zaključkom (Hier., Ep. 1.15).

23 Zaključno sporočilo tega odstavka, pravzaprav besedna igra, zveni zelo, morda celo preveč igrivo: »[...] neque posse eum verba deficere, qui credidisset in Verbum« (Hier., Ep. 1.1).

24 Hier., Ep. 8.2; 9. Glede na kontekst je Enijev citat najbrž vzel iz Varona (Ling. 7.28).

$25 »[\ldots]$ ut in Rhetoricis Cicero ait« (Hier., Ep. 8.2).

26 Hier., Ep. 22.30. 
putabor infirmior, ${ }^{27}$ če pa se mu bo zataknila beseda - kar je ponovno ideja, značilna za topos skromnosti - bo miren vsaj glede namena. Pomembni so v tem odstavku citati klasikov, posebno Vergilija. ${ }^{28}$ Nasploh je metaforika plovbe sredstvo izrazito pesniškega jezika, pa tudi sicer gre pri večini podob, ki jih uporablja, za očitno recepcijo Starih: ${ }^{29}$ jadra, nevarnost, neizkušeni kapitan, varni pristan itd. Hieronim je novi Enej, ki mora preko "morja besed « in čeri, bralca varno pripeljati v pristan, $\mathrm{v}$ domovino, do spoznanja velikih božjih dejanj. Enaka, četudi krajša morska metaforika in iste besede iz Eneide ${ }^{30} \mathrm{mu}$ v drugem pismu služijo ${ }^{31}$ pri poudarku, kako težko se je izviti iz spon grehov. Tudi zaključek je tam enak: varno lahko pristane le ob milosti Svetega Duha. Nepopolna govorica je torej posledica človeške grešne narave in edinole božja milost je primerno sredstvo za rešitev tega problema: tako pomirjen lahko zdaj brez slabe vesti preide na zgodbo.

Tozadevno pa je sama pripoved o mučeništvu ${ }^{32}$ morda še bolj polna retoričnih in literarnih prvin. Že takoj v tretjem odstavku tako izraža svojo nejevoljo nad ravnanjem mladeniča, a tudi občudovanje ženskine kreposti. Ta odstavek je še posebej oblikovno zanimiv, saj Hieronim v njem rabi izrazito metričen jezik, z mnogimi kretiki in spondeji, značilnimi za ciceronsko prozo. ${ }^{33} \mathrm{~V}$ četrtem odstavku primerja konzularisa $\mathrm{z}$ zverjo, $\mathrm{v}$ petem pa $\mathrm{v}$ tipično retorični maniri $\mathrm{z}$ vzklikom izraža sočutje ob mučenju in hkrati občudovanje mučenkine neomajne volje. Podobno je tudi v osmem odstavku, ko retorično vprašanje najprej nadomesti retorični vzklik, ob čudežu pa se ta ponovno izkaže za primerno sredstvo. V nadaljevanju, $v$ devetem odstavku, Hieronim ženskino usodo trikrat primerja z liki

Hier., Ep. 1.2.

»[...] coelum undique et undique pontus«; Ver., Aen. 3.193; 3.195. Slogovno dobrega dela zanj seveda ni brez klasikov; prim. Curtius, Evropska literatura in latinski srednji vek, 44.

Nekaj očitnih mest: Ver., Georg. 2.41; Ovid., Fast. 1.3; Prop., Eleg. 3.3.3; O teh in še mnogih drugih mestih ter o postopnem sprejemanju te metaforike v prozi (npr. Cic., Tusc. 4.5; Plin., Ep. 8.4.5), tudi Hieronimovi, prim. Curtius, Evropska literatura in latinski srednji vek, 123-26. Temeljno študijo, ki je bila nedavno prevedena v slovenščino, je o tej tematiki napisal Hans Blumenberg, Brodolom z gledalcem; prim. 9-46.

o Ver., Aen. 5.9; 3.193. Hier., Ep. 2.

Torej jedro pisma, Hier., Ep. 1.3-14. Kot že nakazano zgoraj, sta uvod in zadnji del pisma (Hier., Ep. 1.15) bržkone nastala kasneje kot jedro, najverjetneje ob objavi; prim. Scourfield, »Literary Commentary on Jerome, Letters 1, 60, 107«, 37. Scourfield, »Literary Commentary on Jerome, Letters 1, 60, 107«, 18-19. 
iz Danielove knjige, ${ }^{34}$ na koncu pa eksplicitno opozori na ironijo, ki se skriva v tem čudežnem dogodku. Vergilij35 mu ponovno služi, da v desetem odstavku izrazi negodovanje nad stražnikovim dejanjem, nato pa opozori še na neobičajno nestanovitnost ljudstva.

Enajsti odstavek, ko je napetost na vrhuncu, saj je usmrtitev tokrat uspešna, je sploh poln retoričnih prvin. Podobno je tudi v dvanajstem, ob čudežu »vstajenja«. Tudi tu je prizor izrazito romanesken - pravzaprav že kar "poezija grobov in noči« ante litteram..$^{36} \mathrm{~V}$ nadaljevanju proti koncu pisma Hieronim ponovno poseže po retoričnih vprašanjih in vzklikih, pripoved pa zaključi še s citatom iz Georgik, ${ }^{37} \mathrm{~s}$ katerim sporoča, da se od teme, četudi bi se dalo še marsikaj povedati, mora umakniti, ${ }^{38}$ a naposled še izrazi lastno zadovoljstvo. Petnajsti odstavek dogajanje hitro, a narativno učinkovito zaključi: Hieronim zgodbo pripelje do sedanjosti, kjer z uvedbo dveh novih likov, svojega mentorja Evagrija in cesarja - ki v dejanskem in prenesenem pomenu presegata provincialni okvir, v katerem se je pripoved do sedaj odvijala - doseže popoln happy ending.

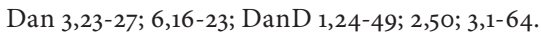

O navezavah drugih Hieronimovih hagiografskih del na antični roman je na voljo nekaj izčrpne sekundarne literature, denimo Šubrt, »Hagiographic Romance: Novelistic Narrative Strategy in Jerome's Lives of Hermits «. Podobno kot v Vita Malchi so tudi v obravnavanem pismu prisotni mnogi temeljni toposi, npr. par zaljubljencev in kruta usoda, ki se na koncu obrne in zaključi v srečen konec; starec, ki se ne vede primerno svojim letom (Hier., Ep. 1.10), ujetništvo idr. Prav tako so v pismu mnogi čudežni preobrati, ki jih denimo Malhov življenjepis ne vsebuje; Šubrt, »Hagiographic Romance«, 205. Skupna značilnost Hieronimovih življenjepisov je, da mu je zgodovinskost naracije manj pomembna in raje poudarja triumf vere ter kreposti nad nemoralo - zato osrednje mesto dobijo kreposti in sposobnosti osrednjega lika, večino zgodbe pa zasnuje ob zapletih z nasprotovanjem, ki jih ta lik doživlja. Epistula prima uvaja tako za njegov korpus značilen tip; prim. Scourfield, »Literary Commentary on Jerome, Letters 1, 60, 107 «, 47. Vsekakor bi si besedilo zaslužilo sistematično primerjavo s pogansko in krščansko antično prozo, a to žal presega meje te razprave - ta cilj še najbolje zasledujejo Coppieters et al., "Martyrdom, Literary Experiment«, na katere se v mnogočem naslanja, čeprav se tudi oni močno omejijo in se osredotočajo predvsem na Hieronimovo subverzijo tradicionalnih spolnih karakteristik.

Ver., Georg. 4.147-148.

8 In tako doda svojemu delu za izobraženo publiko dovolj primeren in konvencionalen zaključek. Za krajši pregled toposov zaključka prim. Curtius, Evropska literatura in latinski srednji vek, 88-90. 


\section{PRIZORIŠČE ZLOČINA - CIVITAS SEMIRUTA}

Vloga Evagrija je pri tem pozitivnem razpletu zanimiva že zato, ker gre za antiohijskega duhovnika, torej za človeka, ki je bil po tedanjih geografskih predstavah s povsem drugega konca sveta, ki pa se zelo zavzeto $^{39}$ vključi v reševanje tega na prvi pogled izrazito lokalnega problema. Poleg vseh ostalih Hieronimovih prekomorskih stikov in potovanj daje bralcem to vedeti, da imajo opravka s predstavnikom ene zadnjih generacij prebivalcev Sredozemlja, ki so se še lahko zanesli na infrastrukturo in varnost rimskega cesarstva ter so uživali živahno mestno in medmestno življenje $\mathrm{v}$ času, ko se je ta manevrski prostor vedno bolj ožil. ${ }^{40}$ Navsezadnje je ravno Hieronim s tem pismom navkljub svojem kozmopolitstvu neposredni znanilec tega propada mest. Podoba, ki jo daje o Vercelah, je namreč jasna: gre za civitas, ki je bila nekoč še potens, dandanes pa je semiruta, na pol v ruševinah. ${ }^{41}$ Te besede so blizu Lukanovemu opisu stanja v Italiji po državljanski vojni v Farzalijah, ${ }^{42}$ in seveda je mogoče pasus interpretirati tudi metaforično, kot aluzijo na "državljansko vojno « med arijanci in pro-nicejskimi kristjani. ${ }^{43} \mathrm{~A}$ tudi dobesedno branje ustvarja podobo, ki najbrž ni preveč sprta $\mathrm{z}$ realnostjo, ${ }^{44}$ sploh če pomislimo, v kako disfunkcionalnem stanju prikaže mestne inštitucije in prebivalstvo. Sodstvo je skorumpirano, ${ }^{45}$ ljudstvo pa zmedeno, domala razrvano. ${ }^{46}$ Toda do propada očitno prihaja postopoma, saj ustanove (sodstvo, zdravnik, arena, duhovščina itd.) navkljub povedanemu načeloma še

Hier., Ep. 1.15 .

Glede te enotnosti mediteranskega prostora, različnih, bolj ali manj napačnih interpretacij zgodovinarjev in dejanske ekonomske involucije mest pozne antike prim. Brown, Vzpon zahodnega krščanstva, 21-31.

Hier., Ep. 1.3.

Luc., Phars. 1.24-27.

Coppieters et al., »Martyrdom, Literary Experiment«, 387-88; tudi Weingarten, The Saint's Saints, 228-29, poudarja, da gre v tem primeru bolj za "moralno « kot dejansko izpraznjenost in da prav to vedno bolj pogosto predstavlja topos.

44 Še toliko bolj je to vidno na primeru točno petdeset let mlajšega galicijskega škofa (in zgodovinopisca) Hidacija, ki je kot desetletnik leta 407 na romanju v Jeruzalem še srečal Hieronima, proti polovici stoletja pa se je čutil že povsem odrezanega od civilizacije in nenazadnje tudi od velikega moža, ki ga je srečal kot otrok: "Malokateri popotnik iz Svete dežele je šel tod mimo. Tako mu niso mogli povedati niti tega, kdaj je umrl Hieronim.« (Brown, Vzpon zahodnega krščanstva, 147).

45 Podoba $\mathrm{z}$ broško je posebno povedna: Hier., Ep. 1.7.

6 Hier., Ep. 1.10. 
delujejo - bolj črnogled bo Hieronim postal v času po Alarikovem vdoru v Italijo (čez njegove domače kraje) na prelomu stoletja. ${ }^{47} \mathrm{Mo}$ goče se namreč prav on od vseh tedanjih avtorjev najbolj tenkočutno odziva na »katastrofične« razsežnosti dobe (in nikakor ne skriva čustev) ter svojo teologijo, posebno eshatologijo, osnuje prav okoli teh družbenih okoliščin. ${ }^{8}$

Toda prav na podlagi tega, da je Hieronim mojster v navezovanju teološke misli na realističen opis družbenih razmer, lahko brez problema sprejmemo obe interpretaciji. Mesto je bilo, posebno glede na bližino čedalje bolj »barbarske« Galije, v resni družbeno-ekonomski krizi, a Hieronim se še kako zaveda tudi verske krize tega dela imperija, ki prav tako odzvanja v njegovi podobi mesta. Sploh je pomenljivo naslednje: Vercele niso neznano mesto, temveč škofijski sedež škofa Evzebija, ${ }^{4}$ ki je bržkone umrl le nekaj let pred nastankom pisma, okrog leta 370, in je bil znan nasprotnik arijanstva ter ustanovitelj škofijske cenobitske ustanove za klerike - torej ustanove, ki jo je glede na svoje monastične pretenzije Hieronim gotovo poznal. ${ }^{50}$ Čisto možno je, da so kleriki s konca pisma, ${ }^{51}$ ki naposled poskrbijo za žensko in so poleg nje načeloma edini pozitivni liki v mestu, dejansko pripadniki tega cenobija. Očitno pomanjkanje lika škofa v zgodbi nakazuje, da je Evzebij res moral nedavno umreti..$^{2}$ Morda je to eno najsubtilnejših ideoloških sporočil, ki jih Hieronim posreduje s pismom. Pokazati

Hilarija in nasprotnik v pismu omenjenega Avksencija v boju proti arijanstvu v severni Italiji in Galiji (Hier., Ep. 1.15). To je bil tudi razlog njegovega izgnanstva na vzhod, kjer je v Antiohiji spoznal Evagrija, ki ga je dobrih deset let pred nastankom tega pisma spremljal nazaj v Italijo. Evagrij je torej Vercele dobro poznal, v desetletju svojega tamkajšnjega bivanja se je uveljavil tudi kot nekakšen voditelj proti-arijanske stranke v severni Italiji in kot predstavniku municipialne aristokracije pomembnega mesta mu je bila odprta pot na cesarski dvor; Rebenich, Hieronymus und sein Kreis, 56-67. V takšni vlogi ga je mladi Hieronim najbrž spoznal, ko se je Evagrij mudil v Akvileji. Verjetno je, da se je Evagrij vrnil v Antiohijo nedolgo pred Hieronimovo potjo na vzhod, torej malo pred nastankom tega pisma. Poznanstvo z njim za Hieronima predstavlja tako temeljno zvezo, ki jo je imel na vzhodu ob svojem prihodu; Rebenich, Hieronymus und sein Kreis, 67-75. »Pristanišče je bilo Maronia, Evagrijevo posestvo, blizu Antiohije; oddaljena obala, v puščavi Halkidi, leto pa 374." (Rousseau, Ascetics, Authority, and the Church in the Age of Jerome and Cassian, 100).

\section{Bratož, Med Italijo in Ilirikom, 288.}

Prim. Bogataj, »Hieronimova eshatologija ob podiranju starega sveta«.

Evzebij iz Vercel, ki je tu škofoval v drugi polovici 4. stoletja, je bil zaveznik Padovese, Uvod v patristično teologijo, 159-160.

Hier., Ep. 1.12-14.

To je povsem v skladu z zgoraj nakazano datacijo. 
želi, kaj se zgodi s krajem, če nima škofa oziroma močne hierarhične strukture Cerkve: mesto propada, ${ }^{53}$ posvetna in povsem nebrzdana oblast se skvari, ${ }^{54}$ moškim upade pogum in se "poženščijo «,, 5 ljudstvo pa kot »a cuncto grege morbida aberrans ovis « ${ }^{56}$ izmenjaje hlepi po okrutnosti ali doživlja množična spreobrnjenja. ${ }^{57}$ Posledice umanjkanja trde roke v cerkvenih zadevah so po Hieronimovem mnenju torej katastrofalne. $\mathrm{V}$ kontekstu podobe, ki jo nariše o izrojeni posvetni oblasti, je še toliko očitneje, kaj je njegov odgovor na razmere - bolj ali manj neodvisne mestne skupnosti, ki jih vodi škof. Prek take vizije družbenega ustroja se morda najjasneje kaže lik Hieronima, ki je ob svojem širokem teološkem delovanju in dolgih epizodah asketskega »klica divjine « v najširšem smislu vendarle prvovrsten cerkveni funkcionar svojega časa. ${ }^{58}$ Nenazadnje je retrospektivno mogoče reči, da je tudi precej daljnoviden - redkokaj je namreč bolj zaznamovalo pozno antiko kot prav vedno trdnejša oblast škofov nad mesti, temi ostanki romanskega življenja sredi iz dneva v dan bolj spremenjene Evrope. ${ }^{59}$

Vse to je še toliko bolj jasno, če predstavlja lik konzularisa ${ }^{60}$ metaforo za celotno posvetno oblast - vsekakor je bil ta v pozni antiki cesarjev neposredni zastopnik v kraju. Hieronim se tu postavi v precej antagonističen, potencialno nevaren položaj $\mathrm{v}$ odnosu do cesarske oblasti. Toliko bolj je potem razumljiv zaključek, ki samega cesarja prikaže v milejši luči, toda tudi tam podoba nikakor ni brezmadežna. ${ }^{61}$ Sploh je sporočilo dovolj jasno: gre za le na videz krščansko oblast,

Hier., Ep. 1.3.

Hier., Ep. 1.3-8; 10-11; 13-15.

Hier., Ep. 1.3-4, 6.

Hier., Ep. 2.7.

Hier., Ep. 1.7; 10; 14.

$\mathrm{V}$ času nastanka tega pisma je bil na začetku svojega cursus honorum - in v tem kontekstu njegova hvalnica Evagriju, uveljavljenemu in vplivnemu cerkvenemu dostojanstveniku, v Ep. 1.15 ni nikakršna posebnost.

59 Nekaj izhodišč odnosa med mestom in škofom v pozni antiki ponuja Brown, Vzpon zahodnega krščanstva, 116-21; 157-70.

6o Lik ostaja neimenovan in na podlagi dostopnih virov praktično nerešljiv problem. Scourfield, "Literary Commentary on Jerome, Letters 1, 60, 107«, 40-41, se poigrava z možnostjo, da bi šlo kar za Ambroža, ki je službo prefekta severne Italije opravljal nekje med 369 in 374 , ko je bil imenovan za škofa, a priznava, da je to malo verjetno - Hieronim namreč ni imel dobrega razloga, da bi pro-nicejskega škofa, četudi anonimno, tako očrnil.

61 Pomenljive so že »lobistične« metode, ki jih je moral ubrati Evagrij; prim. Hier., Ep. 1.15:»[...] precibus fatigat, merito lenit, sollicitudine promeretur«. 
po okrutnosti in skorumpiranosti je enaka nekdanji poganski, ${ }^{62}$ in ta birokracija je tista, ki je »zapravila« imperij. Zaradi nje se širijo krivičnost in herezije, zaradi nje moralno, versko in tudi fizično propadajo Vercele. Coppiters et al. na podlagi Hieronimovega odnosa do "nesrečnega« mladeniča, čigar usmrtitev precej eksplicitno ocenjuje kot pravično, ${ }^{63}$ sicer trdijo, ${ }^{64}$ da Hieronim ne kritizira tedanjega sodnega sistema, toda taka sodba se zdi glede na podobe, predstavljene zgoraj, nekoliko preuranjena. ${ }^{65}$

$\mathrm{V}$ tem smislu je vlogi oblasti podobna, a težje opredeljiva, vloga ljudstva, ki predstavlja v tem nepravičnem, "montiranem « sodnem procesu nekakšno poroto. Stalno omahuje med nasiljem in ubranitvijo žrtve, dokončno jih spreobrne šele drugi čudež. ${ }^{66}$ Manjka jim torej pastir, ki bo v kraj povrnil pravičnost; na koncu ${ }^{67}$ ob odsotnosti lokalnega škofa to vlogo in vse, kar je $\mathrm{z}$ njo povezano (torej v prvi vrsti posredništvo pri cesarju), opravi Evagrij. Bi bilo torej mogoče to besedilo razumeti tudi kot nekakšno priporočilno pismo Evagriju za položaj škofa na izpraznjenem sedežu v Vercelah? Morda je to nekoliko vratolomen zaključek, toda glede na panegirično naravo pisma, Evagrijevo zavezništvo s škofom Evzebijem, njegove zveze v severnoitalijanski Cerkvi in ne tako redko mobilnost te vrste v 4. in 5. stoletju ${ }^{68}$ nemara ni povsem nemogoč.

62 Prim. Hier., Ep. 1.4: [...] ut fera, quae gustatum semel sanguinem semper sitit«.

63 Hier., Ep. 1.3: "[...] solusque omnium miser, merito visus est percuti, quia non reliquit innoxiae, unde posset negare«.

64 Coppieters et al., »Martyrdom, Literary Experiment«, 388.

65 Bolj smiselna bi bila trditev, da Hieronim ves sodni proces oziroma razloge zanj razume kot krivičen odraz samovolje oblasti, ki je šla v svojem iskanju moralne družbe predaleč in celo predstavnike municipialne elite podvrgla sramotnemu mučenju, ki so ga bili sicer deležni le sužnji in nižji sloji. Tak zaključek podkrepijo sočasni viri; Amijan Marcelin, Res gestae, 28.1.11; prim. Scourfield, »Literary Commentary on Jerome, Letters 1, 60, 107«, 38-40. Vsekakor so taki ukrepi pri višjih slojih naleteli na neodobravanje in Hieronimova podoba o okrutnem sodniku in cesarju, ki prošnjo stežka odobri, je kritika teh zakonodajnih sprememb par excellence.

66 Hier., Ep. 1.14.

67 Hier., Ep. 1.15.

68 Glede na nastanek pisma le malo kasnejši milanski škof Marol (škof 408-423) se je, če verjamemo stoletje mlajšemu Enodiju, škofu v Paviji, denimo rodil na bregovih Tigrisa; Ennod., Carm. 2.80.1. 


\section{SEXU FORTIOR SUO - TELO IN ŽENSKA}

Analizo pisma je smiselno nadaljevati s pravnim primerom, ko je pred javnost postavljena obtožba zakonolomstva. Kakšnega zločina je torej kriv mladenič, če ne spolnega delikta, prešuštvovanja, in zakaj se zdi, da Hieronim prav nič ne sočustvuje z njegovo usodo? ${ }^{69}$ Njegova krivda je v njegovi vdanosti v usodo, v njegovem umanjkanju poguma, popustljivosti $\mathrm{v}$ telesnem in duhovnem boju. Vse to pa ni nič drugega kot spolni zločin par excellence, saj se je pregrešil nad lastnim spolom, nad robur virile ${ }^{70}$ - kot tak »ne-moški« pa je po Hieronimovem mnenju že predisponirano nagnjen $\mathrm{k}$ nemorali. Tudi če tega prešuštva $\mathrm{v}$ resnici ni kriv, lahko bralec skupaj z avtorjem zlahka predpostavi, da bi bil, glede na to, da je lažnivec in prevarant, česa takega zlahka sposoben.

Ne le, da je nemožat, svoji vlogi je tudi eksplicitno nedorasel. Zanimivo je, da Hieronim zanj ves čas rabi izraz iuvenis, ${ }^{71}$ soobtožena ženska pa je le sprva muliercula, »ženskica«, v nadaljevanju pa se, bolj kot se izkaže za vzdržljivo v vseh vrstah mučenja, vedno bolj uveljavlja kot femina. ${ }^{72}$ In tudi na začetku, ko je ona še muliercula, je mladenič že kar adulter, ${ }^{73}$ prešuštnik, ki je kriv, še preden je priznal - toda prešuštvo, ki ga je v resnici kriv, tu ni spolne narave, temveč je njegova krivda v pomehkuženosti, ${ }^{74} \mathrm{v}$ pripravljenosti priznavati, confiteri, ko pa bi moral, tako kot krepostna ženska, negare, zanikati. Prav v rabi teh dveh glagolov in njunih sinonimov je pomemben poudarek pri Hieronimovi sprevrnitvi običajne legende o mučeništvu: tradicionalni mučenci izpovedujejo svojo vero, so confessores, obtožena ženska pa bo ohranila krepost le, če bo ves čas zanikala krivo obtožbo. ${ }^{75}$

Takšno paradoksalno kontrastiranje močne, možate ženske in šibkega, poženščenega moškega je značilna tema tako poganskega antičnega romana kot krščanskih mučeniških legend. ${ }^{76} \mathrm{~V}$ pismu

Hier., Ep. 1.3.

Hier., Ep. 1.4.

Hier., Ep. 1.3, 6, 7.

Hier., Ep. 1.7, 10, 12; kot mulier v Hier., Ep. 1.3, 5, 6, 7, 14.

Hier., Ep. 1.3: »[...] oblatam sibi quandam mulierculam una cum adultero«.

O ne tako zelo subtilnih namigih na potrebnost askeze prim. Coppieters et al., »Martyrdom, Literary Experiment«, 390.

Coppieters et al., »Martyrdom, Literary Experiment«, 390-91.

Coppieters et al., »Martyrdom, Literary Experiment«, 389. V nadaljevanju svojega hagiografskega literarnega ustvarjanja se je Hieronim navezav na antični roman redno posluževal - glede teh motivov v dve desetletji mlajši Vita Malchi prim. Fuhrmann, »Die Mönchsgeschichten des Hieronymus«, 65. Tudi 
je najti mnoge topose, značilne za to poznoantično literarno zvrst: ženskino vztrajnost, njeno obračanje $\mathrm{z}$ besedami in očmi na Boga, stopnjevanje sodnikove krutosti. ${ }^{77}$ Hieronim pa gre v svoji izpeljavi morda še nekoliko dlje. Ne le, da je ženska močnejša od mladeniča, tudi politično »dejavnejša « je od njega. Kljub mučenju, ki ga prestaja, zavrne sodnikovo oblast in izpove, da ima le Kristus posest nad dejansko resnico o njenih dejanjih in da je on tisti, ki je edini in pravi iudex.$^{78}$ Prav sodnika bi se dalo označiti za drugi »emaskuliran « lik v zgodbi - medtem ko je žena mirna in zbrana, on besni in hlepi po njeni krvi.79 Ona je paradoksalno racionalna spričo nasilja, sodnik, moški predstavnik oblasti, pa je tisti, ki v resnici »izgubi glavo«. Glede na zgradbo tega odlomka je mogoče brez pretiranega nasilja nad tekstom reči, da se Hieronim še kako zaveda svojega sprevračanja tradicionalnih spolnih vlog. Sodnika, ki ga Hieronim označi z zverjo, fera, ob njeni neomajnosti scela prevzamejo čustva, zapusti ga temperantia in začne groziti celo rablju, če predstavnica šibkejšega spola ne bo priznala, česar moški ni mogel zamolčati: »nisi confiteretur sexus infirmior, quod non potuerat robur virile reticere«. Podivjani sodnik je sicer (tudi po Hieronimovi zaslugi) tipski lik post-nicejskih zgodb o mučeništvu, a tu gre avtor še dlje; skupaj z mladeničem postane resnični primer za sexus infirmior. ${ }^{80}$

$\mathrm{V}$ naslednjem odstavku se razlika med njeno žensko telesnostjo in močjo duha še poglobi. Mučenju so podvrženi njeni osrednji spolni atributi: lasje, crines, so zvezani ob kol, mučitelji se lotijo celo njenih prsi oziroma prsnih bradavic, papillae. ${ }^{{ }_{11}}$ Glede na zasnovo sodnega procesa je, četudi to nikjer v besedilu ni izrecno omenjeno, ta ženska gotovo predstavnica municipialne elite - predstavnikom nižjih slojev namreč niso sodili za prešuštvo. ${ }^{{ }^{2}}$ Spolne konotacije prizora so bile

metaforika v tem delu je zelo podobna tej v obravnavnem pismu - Vita Malchi Hieronim namreč začne $\mathrm{z}$ dolgo primero o mornarjih, ki se v mirnih vodah pripravljajo na bitko (Hier., Vita Malchi 1.1), to pa mu služi kot avtobiografska, a neuresničena napoved, da se bo podal $\mathrm{v}$ »nevarne vode« in pripravil obširno cerkveno zgodovino. Hieronim se je v naslednjih desetletjih večkrat načrtno vračal $\mathrm{k}$ literarnim vrstam in narativnim sredstvom, ki jih je $\mathrm{v}$ obravnavanem pismu prvič preizkušal.

77 Coppieters et al., »Martyrdom, Literary Experiment«, 390.

78 Hier., Ep. 1.6.

79 Hier., Ep. 1.4.

80 Prim. Coppieters et al., »Martyrdom, Literary Experiment«, 393.

81 Hier., Ep. 1.5.

82 Codex Theodosianus 9.7.1: »si vero eius ancilla vel quae ministerium tabernae praebuit, in adulterio fuerit deprehensa, pro vilitate dimittetur«. Prim. Coppie- 
v pozni antiki odvisne od socialnega statusa osebe: razgaljene prsi so pri predstavnici elite torej izrazito ponižujoč, erotičen moment. ${ }^{83}$ Toda sredi mučenja in javnega sramotenja ostaja ženska nepremagljiva: »inmota mulier manet et a dolore corporis spiritu separato, dum conscientiae bono fruitur, vetuit circa se saevire tormenta «. ${ }^{84}$ Njen duh je ločen od njenega telesa, njena telesnost je ne zaznamuje več, paradoksalno celo uživa sadove svoje čiste vesti, conscientia. Zanimivo, že v uvodnem vzkliku tega odstavka Hieronim zanjo ne rabi izraza femina ali mulier, ampak spolno nezaznamovani izraz homo. Mučenje in sramotenje ji torej pomagata, da presega svoj spol in telesnost. Že tu se nakazuje njena prihodnost, ko bo njeno telo po vstajenju očiščeno spolnih atributov - subtilno, a vendarle, začne Hieronim počasi podajati zagovor askeze.

$\mathrm{V}$ polnosti postane to očitno $\mathrm{v}$ dogodkih, ki sledijo njeni usmrtitvi, pokopu in čudežnemu vstajenju. ${ }^{85}$ Celo tako ustaljene reči, kot je menjavanje dneva in noči, se sedaj po božji milosti obrnejo v prid ženske in noč pride prej kot običajno. Bog Stvarnik, ${ }^{86} \mathrm{ki} \mathrm{mu}$ je pokorna vsa narava, tu upogne red stvarstva. Ženska postane kristološki lik, z mučenkinim telesom se godi enako kot z Odrešenikovim in kleriki, odsev Jožefa iz Arimateje, njeno izmučeno telo povijejo v platno in položijo v nov grob. In komaj se stemni, že se ženska kot Kristus v velikonočni noči zbuja k življenju. »Subito feminae palpitat pectus ... $\ll^{87}$ Prsi, ki so bile prej brezobzirno izpostavljene mučenju, so sedaj kraj, kjer se rojeva novo življenje. In ta v krvi prerojena žena odvrže prvotna določila spola in stanu: del telesa, ki je bil pri mučenju še močno spolno zaznamovan kot papillae, ${ }^{88}$ dojke oziroma celo prsne bradavice, postane sedaj nevtralni pectus. Tudi njeno vstajenje ni le navidezni dogodek, ni vstala le kot duh brez materije, ampak je prerojeno celotno njeno telo: »iam spirat, iam videt, iam sublevatur et loquitur .... ${ }^{89}$ To izmučeno telo pa potrebuje čas in mir, da lahko

ters et al., "Martyrdom, Literary Experiment«, 397; Brown, Telo in družba, 41-42.

Coppieters et al., »Martyrdom, Literary Experiment«, 397. Nadaljnja

Hieronimova hagiografska dela še poglobijo to motiviko.

84 Hier., Ep. 1.5.

85 Hier., Ep. 1.12-14.

86 Čudež vstajenja je novo stvarjenje - v čudežni menjavi dneva in noči odzvanjajo besede 1 Mz 1,4-5 v Hieroninovem kasnejšem prevodu: »[...] et divisit lucem a tenebris. Appellavitque lucem Diem, et tenebras Noctem: factumque est vespere et mane, dies unus."

87 Hier., Ep. 1.12.

88 Hier., Ep. 1.5 .

89 Hier., Ep. 1.12. 
do kraja ozdravi in se izogne nadaljnjim preganjanjem - nemudoma ob zori jo namreč že išče »in lictore zabulus «.$^{\circ}$ Liktor, ki jo preganja, je torej sam hudič. Tudi tu je analogija z meniško askezo precej očitna: novo asketinjo takoj začno ogrožati napadi hudiča. Odgovor je jasen, spreobrnitev mora biti popolna in naša prerojena žena nima $v$ pregrešnem mestu več kaj iskati. Še prej pa se mora znebiti preostalih atributov svojega spola: »cum quibusdam virginibus ad secretiorem villulam secto crine transmittitur ${ }^{91}$ Lasje so torej ostriženi in $s$ skupnostjo devic, njenih tovarišic, je poslana $\mathrm{v}$ odročno vilo, njen novi samostan. A tudi tam mora paziti, da vztraja v svoji odpovedi ženskosti: "Ibi paulatim virili habitu veste mutata in cicatricem vulnus obducitur. ${ }^{92}$ Preoblečena je v moška oblačila, ${ }^{93}$ njene rane sicer ozdravijo, a iz njih nastanejo brazgotine - njenega življenja tako nikoli več ne bosta ogrožali lepota in spolna privlačnost, ki sta nenazadnje razlog za celoten proces. Ko je ženska tako rešena omejitev, ki jih nalaga njena spolna in stanovska determiniranost, rešena ženskosti, poroke in zahtev mestnega življenja, naposled zaživi kot svobodna oseba v meniški skupnosti. ${ }^{94} \mathrm{Je}$ nov, že na zemlji poveličan človek,

90 Hier., Ep. 1.13.

91 Hier., Ep. 1.14.

92 Hier., Ep. 1.14.

93 O menjavi spolnega izraza kot pogostem motivu v krščanski tradiciji prim. Coppieters et al., "Martyrdom, Literary Experiment«, 405; Acta Pauli et Theclae, 40. Podrobno ta motiv obravnava Hunt, Clothed in the Body: Asceticism, the Body and the Spiritual in the Late Antique Era, 63-79.

94 Coppieters et al., „Martyrdom, Literary Experiment«, 406, do določene mere legitimno, a morda prehitro pripomnijo, da je junakinja bore malo svobodna: prešuštva jo obtoži mož, izda jo mladenič, sodi sodnik, muči mučitelj, obvarujejo in v askezo pošljejo kleriki in naposled jo reši Evagrij. Zdi se, da so protagonisti njene zgodbe moški in ne ona sama? Gotovo Hieronim ni feminističen avtor $\mathrm{v}$ sodobnem pomenu besede, a ni mogoče spregledati učinka ženskine volje kot prostora, kjer se uveljavlja njena svoboda - s svojo vztrajnostjo v kreposti premaga in osramoti vse, ki ji nasprotujejo, naposled celo smrt. Vlogo klerikov pri odločanju o njenem prihodnjem življenju v meniški skupnosti je potrebno razumeti tudi v kontekstu zagovora askeze, ki ga Hieronim vnaša v pismo; kot nova asketinja je deležna duhovnega vodstva, ki je običajen element na asketski poti. Sploh je pomembno ob tem vprašanju poudariti, da je Epistula prima nastala v času, ko se je Hieronim uveljavljal kot origenistično navdahnjen mislec, ko je torej še delil Origenove nazore o fluidnosti človeškega telesa in preseganju spolne razlike; prim. Brown, Telo in družba, 215-17. Ne le to - origenistično vizijo družbe je $\mathrm{v}$ letih po nastanku pisma načrtno uveljavljal tudi v praksi s pomočjo bogatih rimskih vdov, posebno Marcele in Pavle, dokler ni sredi zadnjega desetletja 4. stol. z Origenom usodno presekal; Brown, Telo in družba, 455-64. 
ki sedaj lahko vstopa v novo dobo krščanstva. Ves čas je ostala tako zavezana virtus, da je na koncu postala vir.

$\mathrm{S}$ tem se počasi nakazuje sklep. Ne glede na zgoraj omenjeno Hieronimovo željo po idealni družbeni ureditvi mesta kot urejene, umirjene krščanske skupnosti pod vodstvom pravovernega škofa je v času pisanja pisma Stridončana Kristusovih let vleklo stran od mesta, na podeželje, v pustinjo in samoto, ${ }^{95} \mathrm{kjer}$ so nastajale civitates Dei - samostani kot novi prostori krščanske omike in civilizacije, kot kraji prihodnosti. Ta se tu že živi na konkreten, eshatološki način. Samostani predstavljajo božje mesto, novi Jeruzalem, sredi napol porušenih ${ }^{96}$ človeških mest nekoč mogočnega imperija. Kot sporoča Epistula prima, so mesta kraji civilizacijskega in moralnega propada in razuzdanosti, v njih se bohotijo herezije in oblastniško nasilje. Odročne podeželske villulae so njihov antipod, tam so doma vrline, pravoverno krščanstvo in pravo bogočastje, ki bo preživelo propad civilizacije sredozemskih mest - tam so doma tudi device in žene, katerih volja in vztrajnost $\mathrm{v}$ askezi presega celo mestne oblastnike.

Kakor je do začetka 4. stoletja po Kr. figura mučenca med kristjani veljala za nesporen zgled in idealno podobo, tako jo je v 4. stoletju izpodrinila podoba asketa. Krvavemu mučeništvu je sledilo belo mučeništvo - meništvo. Pričevanje je ostalo, spremenila so se njegova orodja in izrazi. Bližino in preplet obeh tematik - pravzaprav dobeseden prehod iz mučeništva $\mathrm{v}$ meništvo - posreduje ravno pričujoča umetelna literarna vaja mladega asketa Hieronima. Upravičeno je torej domnevati, da novica, ki jo želi razširiti preko Inocencija v svet, ne govori toliko o krepostni ženski niti o neizrekljivem čudežu, ki je na meji verjetnega, ampak o novi formi izražanja krščanske vere v meništvu. To novost znotraj krščanstva, ki je prvi dve stoletji praktično nista poznali - vsaj ne v taki obliki in razširjenosti - je Hieronim umestil v jasno kontinuiteto $\mathrm{z}$ mučeništvom, ki pa ima $\mathrm{v}$ krščanstvu absolutno domovinsko pravico. S tem na portal svojega pisanja ni postavil zgolj apologije svoje odločitve za puščavo in legitimizacije nove krščanske askeze, ampak je iz tega naredil celo nekakšno vabilo, naj mu sledijo še drugi, kar bo eksplicitno ponovil še v številnih naslednjih pismih. ${ }^{97}$ Prav tako so vsi trije njegovi kasnejši samostojni svetniški življenjepisi - Vita Pauli (ok. 376), Vita Malchi (ok. 391) in približno sočasna Vita

Za kratek biografski pregled Hieronimovega prvega »asketskega poskusa « v času nastanka obravnavnega pisma prim. Rousseau, Ascetics, Authority, and the Church in the Age of Jerome and Cassian, 99-108.

97 Hier., Ep. 14; 22; 52; 71. 
Hilarionis - ki nadaljujejo literarno vrsto omenjenega pisma, v prvi vrsti zelo načrtno propagiranje askeze. To pomembno temo Hieronimovega literarnega korpusa kot prva načenja prav Epistula prima.

\section{BIBLIOGRAFIJA}

Barnes, Timothy David. Early Christian Hagiography and Roman History. Tübingen: Mohr Siebeck, 2016.

Blumenberg, Hans. Brodolom z gledalcem: Paradigmna metafore bivanja. Ljubljana: Krtina, 2018.

Bogataj, Jan Dominik. »Hieronimova eshatologija ob podiranju starega sveta«. Pogovori 20, št. 1 (2018): 26-28.

Bratož, Rajko. Med Italijo in Ilirikom: Slovenski prostor in njegovo sosedstvo $v$ pozni antiki. Ljubljana: Slovenska akademija znanosti in umetnosti, 2014.

Brown, Peter Robert Lamont. Telo in družba: Spolno odrekanje v zgodnjem krščanstvu. Ljubljana: Studia humanitatis, 2007.

- Vzpon zahodnega krščanstva: Zmagoslavje in raznoličnost, 200-100o n. š. Ljubljana: Založba /*cf., 2006.

Cain, Andrew. The Letters of Jerome: Asceticism, Biblical Exegesis, and the Construction of Christian Authority in Late Antiquity. Oxford: Oxford University Press, 2010.

Coppieters, Steff, Annelies Bossu, Danny Praet in Maarten Taveirne. »Martyrdom, Literary Experiment and Church Politics in Jeromes Epistula Prima, to Innocentius, on the septies percussa». Vigiliae Christianae 68, št. 4 (2014): 384-408.

Curtius, Ernst Robert. Evropska literatura in latinski srednji vek. Ljubljana: Literarno-umetniško društvo Literatura, 2002.

Fuhrmann, Manfred. »Die Mönchsgeschichten des Hieronymus: Formexperimente in erzählender Literatur«. V: Christianisme et formes littéraires de l'antiquité tardive en Occident, ur. O. Reverdi, 41-89. Ženeva: Entretiens Hardt, 1977.

Hunt, Hannah. Clothed in the Body: Asceticism, the Body and the Spiritual in the Late Antique Era. Milton: Routledge, 2016.

Movrin, David. Fidus interpres $=$ Zvest prevajalec. Ljubljana: Založba ZRC, ZRC SAZU, 2010.

Padovese, Luigi. Uvod v patristično teologijo. Ljubljana: Frančiškanski samostan, 1994.

Potisek, Janez, Jan Dominik Bogataj in Domen Iljaš, prev. »Hieronim: Pisma 1, 2, 8, 9«. Tretji dan 47, št. 9/10 (2018): 47-52. 
Rebenich, Stefan. Hieronymus und sein Kreis: Prosopografische und sozialgeschichtliche Untersuchungen. Stuttgart: Steiner, 1992. - Jerome. London: Routledge, 2002.

Rousseau, Philip. Ascetics, Authority, and the Church in the Age of Jerome and Cassian. Notre Dame: University of Notre Dame Press, 2010.

Scourfield, J. H. David. »A Literary Commentary on Jerome, Letters 1, 60, 107«. Doktorska disertacija. Oxford: Univerza v Oxfordu, 1984. Šubrt, Jiří. »Hagiographic Romance: Novelistic Narrative Strategy in Jerome's Lives of Hermits«. V: The Ancient Novel and the Frontiers of Genre, ur. Maríla P. Futre Pinheiro, Gareth L. Schmeling in Edmund P. Cueva, 205-14. Groningen: Barkhuis, 2014.

Weingarten, Susanne. The Saint's Saints: Hagiography and Geography in Jerome. Leiden: Brill, 2005. 


\section{IZVLEČEK}

Razprava se ukvarja $\mathrm{z}$ analizo prvega pisma iz Hieronimove korespondence. Avtor je imel do njega očitno ambivalenten odnos, kar kliče k iskanju večplastne sporočilnosti spisa. Po poskusu datacije, retorični in slogovni analizi ter predstavitvi osnovne zgodbe, ki je vključena vanj, se pokaže, da je pismo kljub navidezni hagiografski šablonskosti vsebinsko bogato. Analiza se zato nadaljuje na dveh področjih. Kraj dogajanja, poznoantično mesto, ne more preživeti brez nove vodilne osebnosti, škofa. Je s pismom Hieronim želel tlakovati pot na vercelski škofovski sedež prijatelju Evagriju iz Antiohije? Ob analizi nejasnih spolnih identitet obeh glavnih oseb iz zgodbe, nemoškega mladeniča in moško neuklonljive ženske, se pokaže, da je Hieronim v novem času iskal nov krščanski ideal, meništvo, ki ga je preko te zgodbe umestil v kontinuiteto $\mathrm{z}$ mučeništvom.

KLJUČNE BESEDE: Hieronim, epistolografija, hagiografija, spolna identiteta, mučeništvo, meništvo 
O VERE IUS SUMMUM, SUMMA MALITIA:

THE GENRE AND INTENT OF JEROME'S EP. 1

\section{ABSTRACT}

The paper analyses the first letter from the correspondence of Saint Jerome. The author had a somewhat ambivalent attitude towards the text, and this fact provides the basis for exploring its multi-layered communication. After an attempt at dating, rhetorical and stylistic analysis, and presentation of the basic embedded story, the examination continues on two challenging levels. The late-antique town was not capable of surviving without a new type of leading personality, namely the bishop. Jerome may have planned to pave the way to the bishopric of Vercelae for his friend Evagrius of Antioch. The analysis of the unclear gender identities of both protagonists of the story, the less-than-manly young man and the manly and unbreakable woman, shows that Jerome was trying to establish a new ideal for Christians, one based on monastic asceticism and in continuity with martyrdom.

KEYWORDS: Jerome, epistolography, hagiography, gender identity, martyrdom, monasticism 